\title{
高強度および高耐衝撃性を備えたベイナイト鋼の開発
}

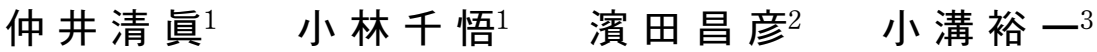

\author{
1愛媛大学大学院理工学研究科物質生命工学専攻機能材料工学コース \\ 住友金属工業株式会社総合技術研究所 \\ 3 大阪大学接合科学研究所
}

J. Japan Inst. Metals, Vol. 70, No. 11 (2006), pp. 874-879

Special Issue on Development on Materials for Automobiles Use

(C) 2006 The Japan Institute of Metals

OVERVIEW

\section{Development of Bainitic Steel with High-Strength and -Resistance to Shock}

\author{
Kiyomichi Nakai1, Sengo Kobayashi¹, Masahiko Hamada² and Yu-ichi Komizo ${ }^{3}$ \\ ${ }^{1}$ Course of Materials Science and Engineering, Department of Materials Science and Biotechnology, \\ Graduate School of Science and Engineering, Ehime University, Matsuyama 790-8577 \\ ${ }^{2}$ Corporate R \& D Lab., Sumitomo Metal Industries, Ltd., Amagasaki 660-0891 \\ ${ }^{3}$ Joining and Welding Res. Inst., Osaka University, Ibaraki 567-0047
}

Intragranular bainite $(\alpha)$, which consists of 24 variants formed at random, in steels has been investigated in order to develop both strength and toughness. The orientation relationship, $\{011\} \alpha / /\{111\} \gamma,\langle 11 \overline{1}\rangle \alpha / /\langle 10 \overline{1}\rangle \gamma$ and $\langle\overline{2} 1 \overline{1}\rangle \alpha / /\langle\overline{1} 2 \overline{1}\rangle \gamma$, between intragranular bainite and austenite $(\gamma)$ has been analyzed to be an important controlling factor for toughness. It could be suggested that the increase in the number density of nucleation site for lath of intragranular bainite increases in both strength and toughness of bainitic steels.

(Received May 2, 2006; Accepted July 12, 2006)

Keywords: intragranular bainite, crystallography, orientation relationship, stereographic analysis, parallelism of slip system, toughness, strength

1.は じめに

自動車用材料としては地球温暖化の抑制および燃費の低減 を目指してその軽量化が図られている。すでに，自動車用材 料として高強度鋼を随所に用いて，その使用量を減らすこと による軽量化が図られて抢り，かつ，耐衝撃性の鉄鋼材料の 開発をも目指されている.

そこで，本論文では鉄鋼材料中に生成される微細組織の一 つであるべイナイトを利用して高強度かつ高勒性材料の設計 の試みを紹介する. ベイナイトは, サイズがサブ・ミクロン の微細組織であることから高強度が期待されるが，バリアン 卜 (variant; 兄弟晶)の結晶学的制御に基づいて勒性の向上 をより一層図る必要がある. そこで, 本論文では勒性に及ぼ す結晶学的効果に関する検討結果を述べ，かつ，その組織制 御法について記述する.

\section{2. ベイナイトの結晶学}

ベイナイト $(\alpha ; \mathrm{bcc}$ 構造 $)$ は, 過冷オーステナイト $(\gamma ; \mathrm{fcc}$ 構造)の等温保持下で鋭い表面起伏を伴って生じ, その形状 はラス(細長い板)状であり, 核生成箇所は結晶粒界とされ る.ベイナイトはその結晶学的形態によって上部ベイナイト
と下部ベイナイトに大別される.これらは母相である過冷 オーステナイトの晶癖面を異にし, 下部ベイナイトは〜 0.4 $\operatorname{mass} \% \mathrm{C}$ 以上の鋼のみに生成され, その晶癖面は $(254) \gamma$ 〜 / (122) $\alpha$ である ${ }^{1)}$. 一方, 上部ベイナイトは, $\{111\} \gamma$ 面 を晶癖面とするが， 3 種の型， B- I ，一II 抢よび-III，に分別 される. B- I 型は炭化物生成を伴わない。 B-II 型は $\{111\} \gamma$ 面上, つまり晶㾕面上に炭化物生成を伴う。この面は, ベイ ナイト・ラスの $\{110\} \alpha$ 面に対応する. B-III型はベイナイ ト・ラス中に炭化物生成を伴うが，1つの面上，(314） $\alpha / /$ $(4 \overline{1} 4) \gamma$ 面，にのみ炭化物が生成されている。したがって, その組織を観察すると, 一方向のみに炭化物が並んでいる. 一般に, 過冷オーステナイトの保持温度が高温である程, B- I 型が生成されやすく, 保持温度が低下するにつれて BII 型, B-III型が生成される. ベイナイト中の炭化物生成は ベイナイトの特長でもあるが，一方で欠点になることもあ る。つまり，割れの起点になることがある.

ベイナイト・ラスは, 特に平均サイズが $1 \mu \mathrm{m}$ 以下と細か く, 超微細粒材料中の結晶粒径に匹敵する. しかし, 超微細 粒材料中の結晶粒 (等軸粒) は, 結晶学的にほぼ無秩序に配列 しているが，ベイナイト・ラスは，母相である過冷オーステ ナイトとKurdjumov-Sachs (K-S)の方位関係, $\{011\} \alpha / /$ $\{111\} \gamma,\langle 11 \overline{1}\rangle \alpha / /\langle 10 \overline{1}\rangle \gamma$ および $\langle\overline{2} 1 \overline{1}\rangle \alpha / /\langle\overline{1} 2 \overline{1}\rangle \gamma$ ，を有す る。したがって, 特に变形初期ではシュミット(Schmid)因 


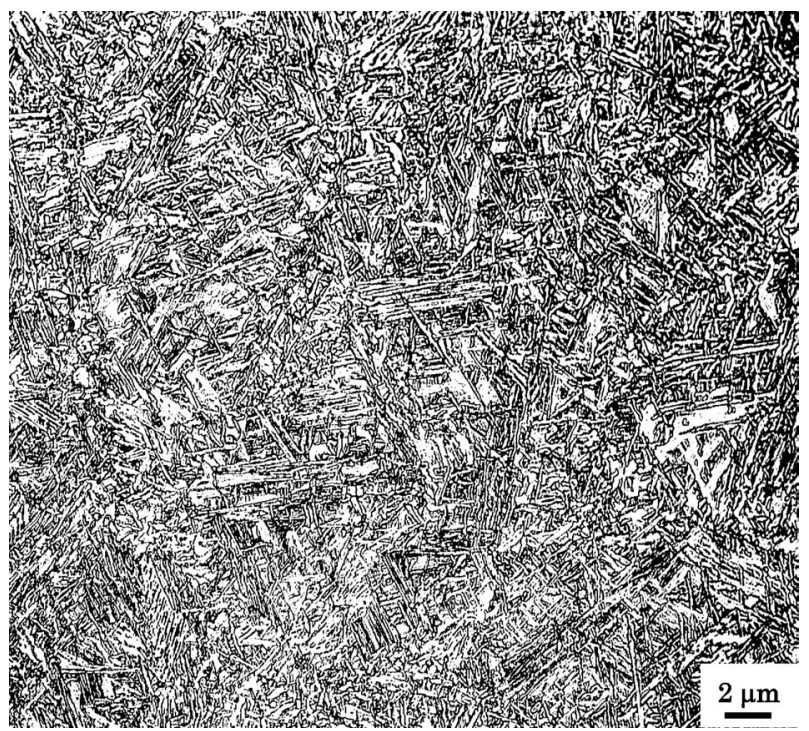

Fig. 1 Optical micrograph taken from intragranular upper bainite laths in a $\mathrm{Fe}-0.15$ mass\% $\mathrm{C}$ steel.

子に依存して変形が進行するので2)，この K-S の方位関係 の有無が変形過程に影響を及ぼす可能性が大である。つま り，一個のベイナイト・ラスが剪断変形すると，隣接するべ イナイト・ラスによってその剪断歪が緩和される可能性があ る. 隣接するべイナイト．ラス中のすべり系同士の平行性 (すべり面抢よびすべり方向の平行性)が良好であると, 剪断 歪が隣接するべイナイト・ラスの変形によって緩和されやす い.しかし，100\%の緩和は望めず，最初に変形したべイナ イト・ラス中に残留する剪断歪は, 隣接するべイナイト・ラ ス中の平行すべり系以外のすべり系の活動によって緩和され ると考えられる.これによっても緩和されない場合には, 材 料破断の要因の一つになるものと考えられる.

よって, 超微細粒材料を想定して無秩序に結晶粒が配向し ている場合と， 24 種類のバリアントから成るベイナイト・ ラスが無秩序に配列している状態 (以後, この状態のベイナ イトを粒内ベイナイトと称する) とを考え, 隣接する結晶粒 間あるいはべイナイト・ラス間のすべり系の平行性を定量的 に解析し，その変形過程に及ぼす効果について説明する. 粒 内ベイナイトの光学顕微鏡写真を Fig. 1 に示す. 粒内ベイ ナイトの場合は 24 種のバリアントがほぼ均等, かつ, 無秩 序に生成した状態であり，この状態を反映してべイナイト。 ラスが多方向に成長している. また, 大きな特徴として, 平 行なベイナイト・ラスの大きな集団(塊り)がほとんど見られ ず，一個一個のベイナイト・ラスが隣接するべイナイト・ラ スとは異なる方向に成長していることである. さらに, 超微 細粒材料と大きく異なる点は, 母相である過冷オーステナイ トと K-Sの結晶方位関係を有することである．この点は， 特にベイナイト鋼の高勒性化に結び付く可能性が高い3-9). また, ベイナイト・ラスによるブロック等の変形過程に及ぼ す効果についての解析結果も報告する.

\section{3. すべり系の平行性}

Fig. 2 に示すようにベイナイト・ラス 1 で変形が生じ始め

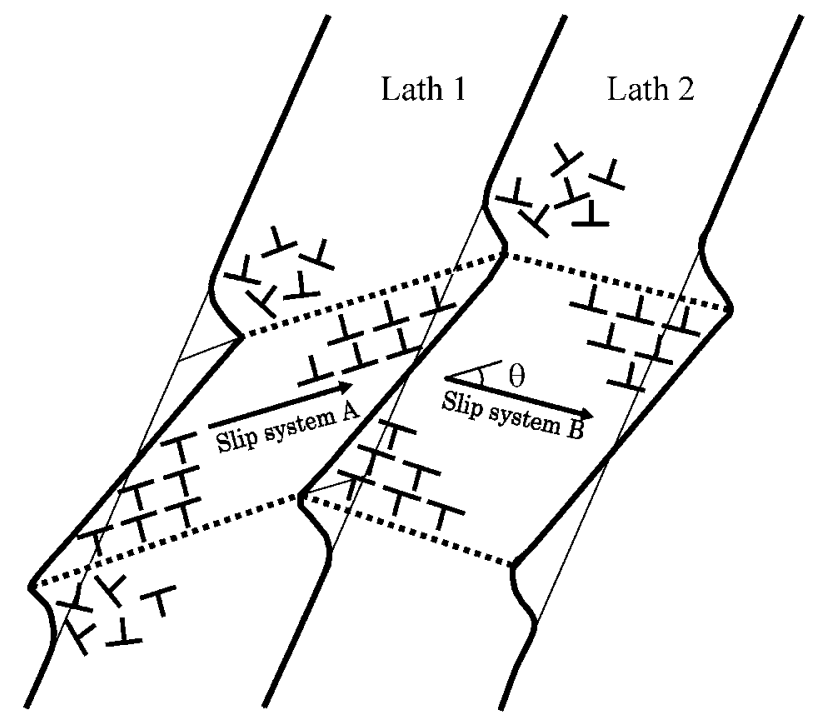

Fig. 2 Schematic illustration of deformed bainite laths. Almost of shear strain might be relaxed with deformation of neighboring bainite lath, which is induced by slip system with large Schmid factor. Remained strain is relaxed by activation of slip systems with small Schmid factors. Fine solid lines indicate initial shape of bainite laths and thick lines indicate deformed shape. The symbol $\perp$ is dislocation. The region between dotted lines is sheared by activation of slip system with large Schmid factor.

るとすると，図に示すように剪断歪が発生する，このときべ イナイト・ラス 1 内のすべり系 A が活動したとする。そう するとこのすべり系 $\mathrm{A}$ に対して平行に近いすべり系 B が活 動しやすいと考えられ, かつ, ベイナイト・ラス 1 内の剪 断歪も隣接するべイナイト・ラス 2 の変形によって緩和さ れやすいと考えられる. Fig. 3 に見られるようにラス界面の 一部(〔で囲まれた領域)では隣接した部分で高密度の転位 が見られ, かつ, 剪断歪によってその界面部分が他の界面部 分から折れ曲がって見える.つまり, ベイナイト・ラス 1 で生じた剪断歪, $\varepsilon_{1}$, の大部分がベイナイト・ラス 2 の変形, $\varepsilon_{2}=\varepsilon_{1} \cos \theta$ (Fig. 2 参照 $; \theta$ はすべり系 $\mathrm{A}$ と B との成す角 度), によって緩和され, ベイナイト・ラス界面での過度 (高 密度)の転位の集積が避けられ材料の伸びを助長することに なると考えられる. Fig. 2 は理解を促すためにすべり方向 A と B とが同一平面上にある場合を想定している. ベイナイ ト・ラス間のすべり系，すべり面抢よびすべり方向，の平行 性が良い程, $\theta$ の值は減少し, ベイナイト・ラス 2 による歪 緩和量, $\varepsilon_{1} \cos \theta$, は増大することになる. ベイナイト・ラ ス 1 と 2 に打害べり面同士の平行性についても同様の 傾向にあり, 平行性が良い程, ベイナイト・ラス 1 中で生 じた剪断歪がべイナイト・ラス 2 中のすべり面の剪断歪を 効率良く誘起する傾向になるのは明白である.

したがって, 両ラス間のすべり方向およびすべり面の平行 性が, ベイナイト・ラスの場合と超微細粒材料の場合とで如 何に異なるのかを検討する. まず，ベイナイト・ラス間のす べり系の平行性について検討した. この検討に当っては, ス テレオ投影図を利用した. ベイナイト・ラスには 24 種類の バリアントが存在するが，まず，オーステナイトの (111) $\gamma$ 標準投影図を準備した。この (111) $\gamma$ 標準投影図を基準に採 


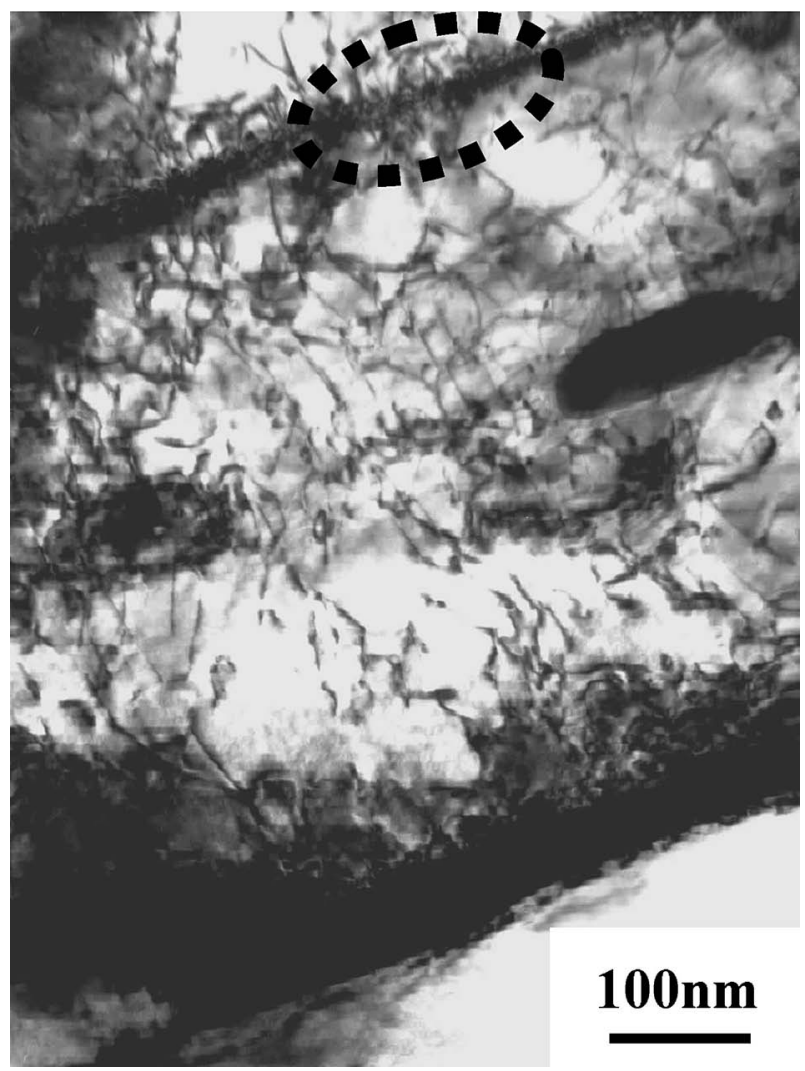

Fig. 3 The interface between bainite laths deformed with shear stress, enclosed with dotted line. Relatively high density of dislocations at the interface exist.

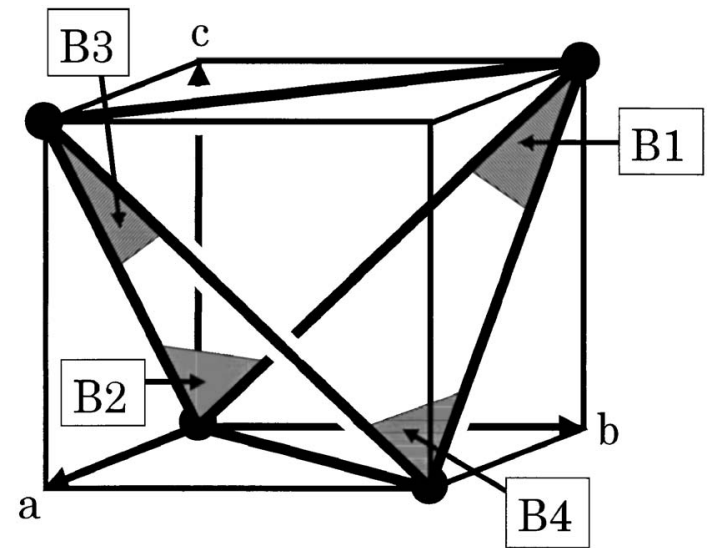

Fig. 4 Thompson tetrahedron in a fcc lattice with crystallographic axes, a, b and c.

り，K-S 方位関係を有するべイナイト・ラスのステレオ投 影図を作成した。ところで，ベイナイト・ラスは，オーステ ナイト中の 4 枚の $\{111\} \gamma$ 面を晶癖面とし，各晶癖面につき 6 種類のバリアントが存在する．したがって，ベイナイト． ラス間のすべり系の平行性を検討するに当っては, Fig. 4 に 示すトンプソン四面体を参考とする. 例えば Fig. 4 中のト ンプソン四面体の B1 面上に 6 種類のベイナイト・ラス・バ リアントが存在し，これに対応して 6 枚のステレオ投影図 を必要とする(Fig. 5)。このB1 面を晶癖面とするバリアン 卜間については，すべり面扔よびすべり方向の平行性を上記 の 6 枚のステレオ投影図を利用して解析する。 ベイナイ
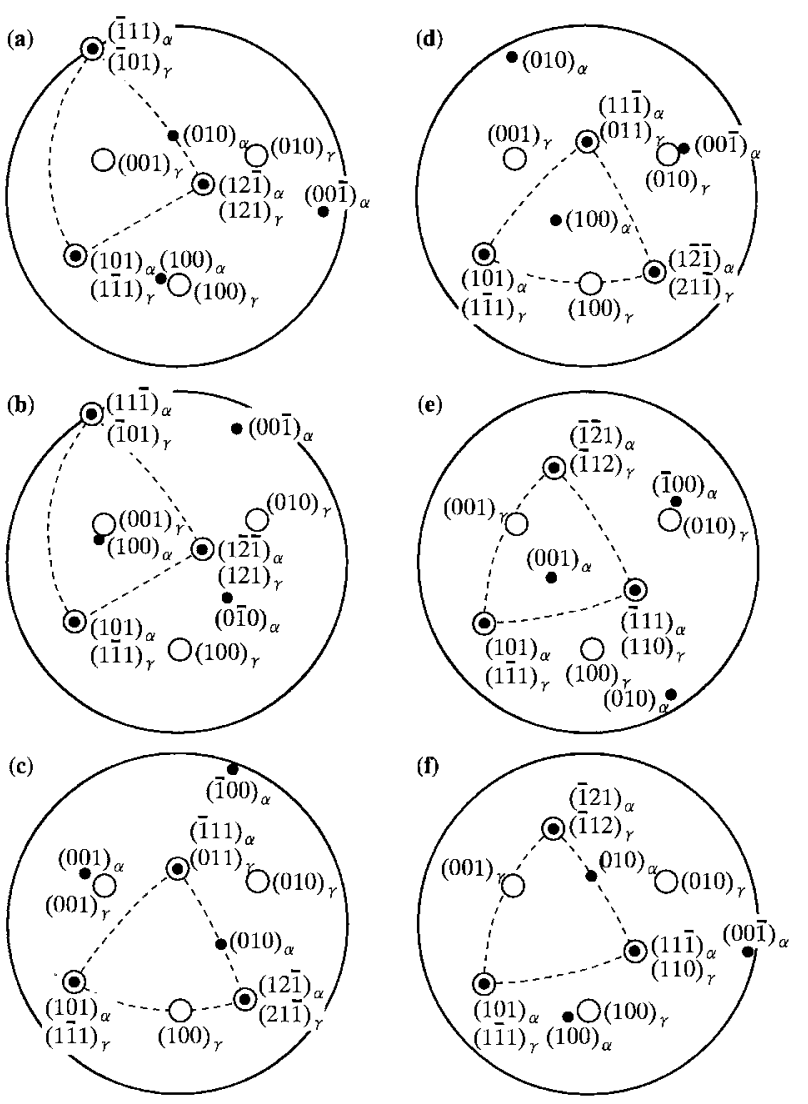

Fig. 5 Stereographic projections for crystallographic directions in 6 variants with habit plane of $(1 \overline{1} 1) \gamma$.

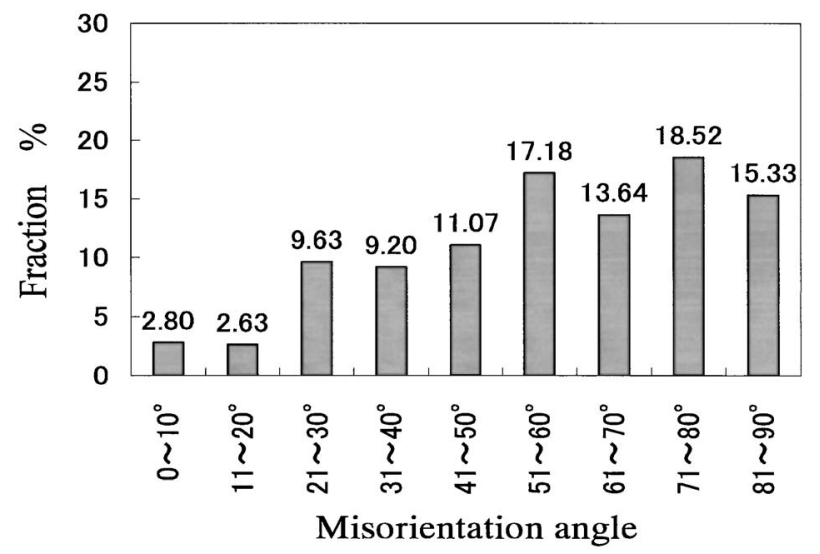

Fig. 6 Distribution of misorientation angle between directions normal to slip planes in B1-variants with Kurdjumov-Sachs orientation relationship.

ト・ラスのすべり面としては，1個のバリアントについて 6 種の $\{110\} \alpha$ および 12 種の $\{112\} \alpha$ を考える.つまり，Fig. 5 中の 6 枚のステレオ投影図を重站て $\{110\} \alpha$ 抢よび $\{112\} \alpha$ 間の角度を計測する．但し，ここでは $20^{\circ}$ 以下の角度を成す すべり面同土を「平行性が良いすべり系」として採り上げ る. 理由は, $20^{\circ}$ という角度が小傾角粒界を挟んだ結晶粒同 土が成す最大角にほぼ匹敵するからである，面間角度の計測 に当っては, 約 4900 組が対象となるが，これらの結果を図 にまとめたものが Fig. 6 である. 全すべり面の内の $5.43 \%$ が $20^{\circ}$ 以下である．次に，すべり面同士が $20^{\circ}$ 以下のすべり 


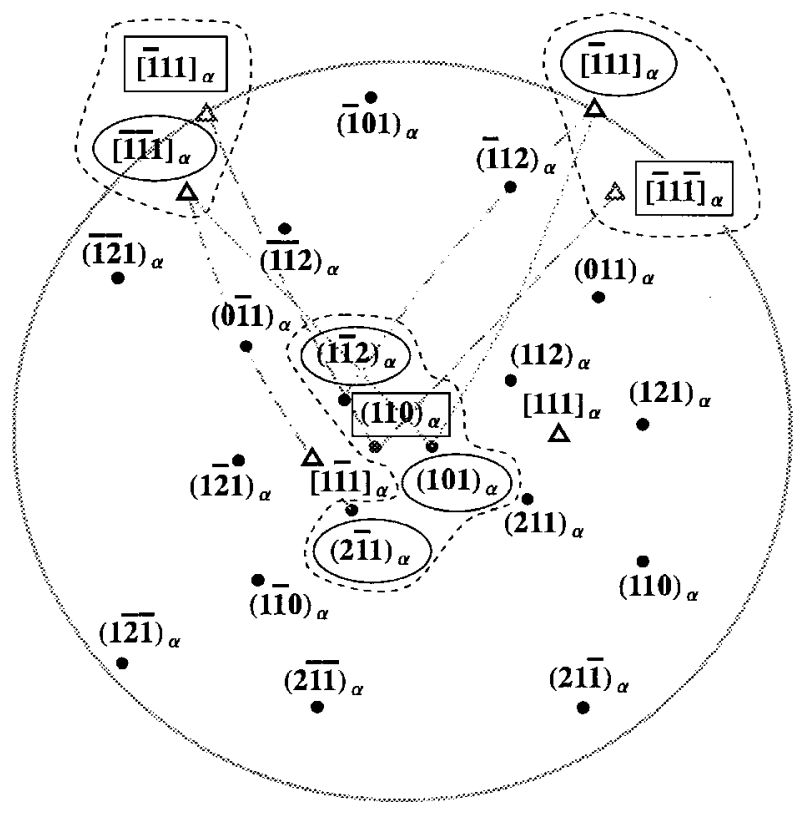

Fig. 7 Slip systems enclosed with $\square$ are in a variant. Slip systems enclosed with $\square$ are in another variant. In this case, both slip planes and slip directions are parallel with each other within $20^{\circ}$, which are enclosed with dotted line.

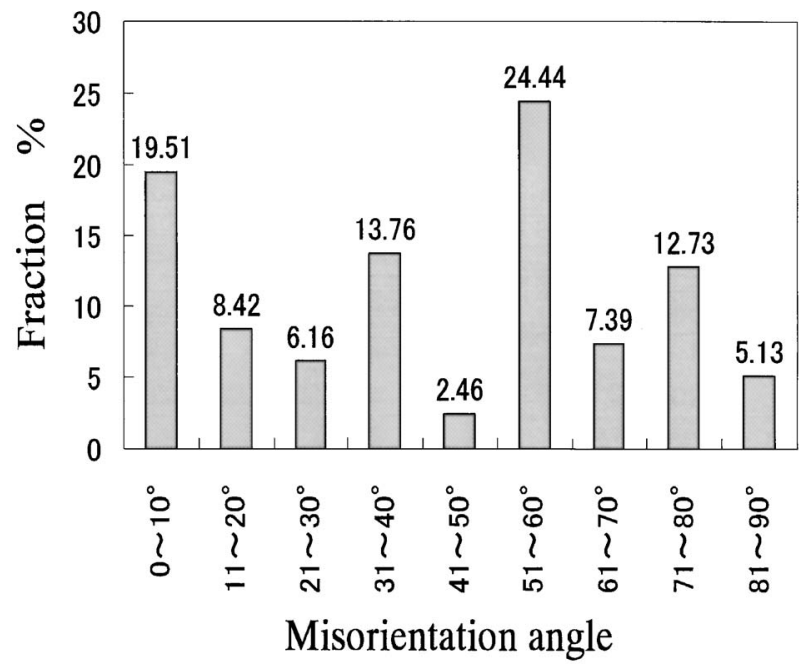

Fig. 8 Distribution of misorientation angle between slip directions in B1-variants with Kurdjumov-Sachs orientation relationship.

系の内, すべり方向, $\langle 111\rangle \alpha$, 同士が $20^{\circ}$ 以下のものの存在 割合を解析した結果を示す. $\{110\} \alpha$ については，1つの面 につき 2 方向のすべり方向， $\{112\} \alpha$ については， 1 つの面 につき 1 方向のすべり方向が存在する. その解析の様子の 一例として Fig. 7 を示す。例えば，Qで囲んだ 2 方向， $[\overline{1} 11] \alpha$ と $[\overline{1} \overline{1} 1] \alpha ， の$ 間の角度をウルフネット上の大円に沿 って計測している.この結果を Fig. 8 に示す.この結果か らすべり方向の平行性が良いものの割合は $27.93 \%$ となり, すべり面およびすべり方向の両方の平行性が良いものの割合 は， $0.0543 \times 0.2793 \times 100=1.52 \%$ でる.

以上は, B1 面 (Fig. 4) 上に存在する 6 種類のバリアント 間に関する解析結果であったが，次に異なる晶癖面間のバリ アントについて考える. B1 面上に存在するバリアントと B2

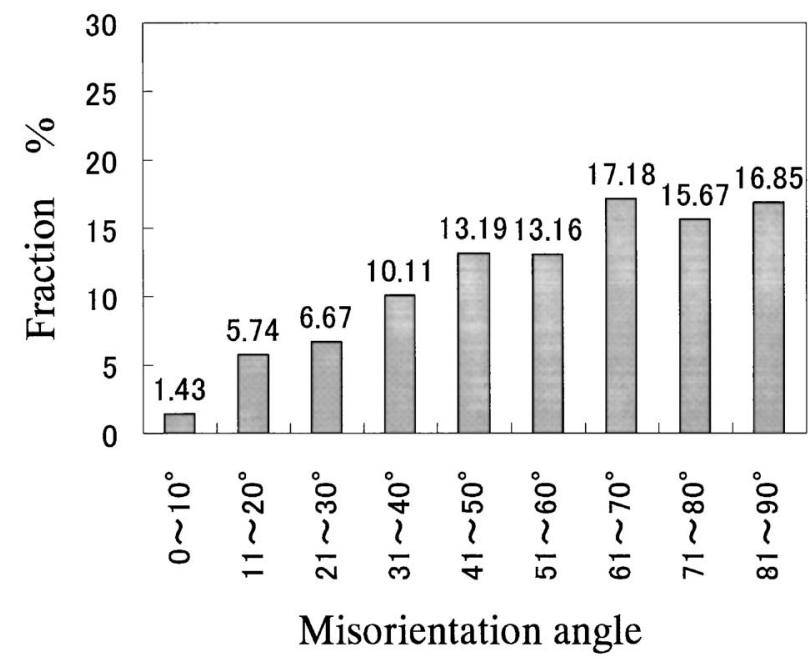

Fig. 9 Distribution of misorientation angle between directions normal to slip planes in B1- and B2-variants of bainite lath with Kurdjumov-Sachs orientation relationship.

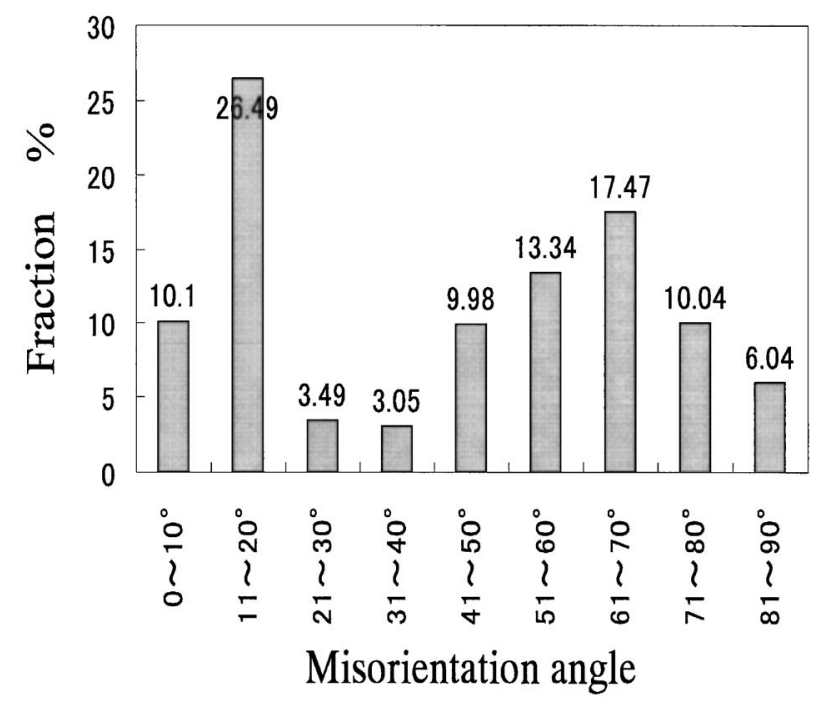

Fig. 10 Distribution of misorientation angle between slip directions in $\mathrm{B} 1-$ and B2-variants of bainite lath with Kurdjumov-Sachs orientation relationship.

面, B3 面抢よび B4 面上のバリアントとは互いに結晶学 上，同一の配向を取ることになるので，B1 面上のバリアン トと B2 面上のバリアント間ですべり系の平行性を検討すれ ば良いことになる．この B1 面上のバリアントと B 2 面上の バリアント間での平行性が良いすべり系の存在割合を $(3 / 4)$ 倍し, B1 面上のみのバリアント間の平行性が良いすべり系 の存在割合を $(1 / 4)$ 倍して加えたものが系全体に対して存在 する平行性が良いすべり系の存在割合ということになる.

そこで，まず， B1 面上のバリアントと B 2 面上のバリア ントの間でのすべり面の平行性について解析した，面間角度 の計測にあたっては, 約 12000 組を対象とせねばならない が，これらの結果を図になとめたものが Fig. 9 である.す ベり面同士の平行性が良いものは，7.17\%である。この内, すべり方向に関しても平行性が良いものは，36.59\%であっ た (Fig. 10 参照)。したがって，すべり面およびすべり方向 の両方の平行性が良いものは， $0.0717 \times 0.3659 \times 100=$ 

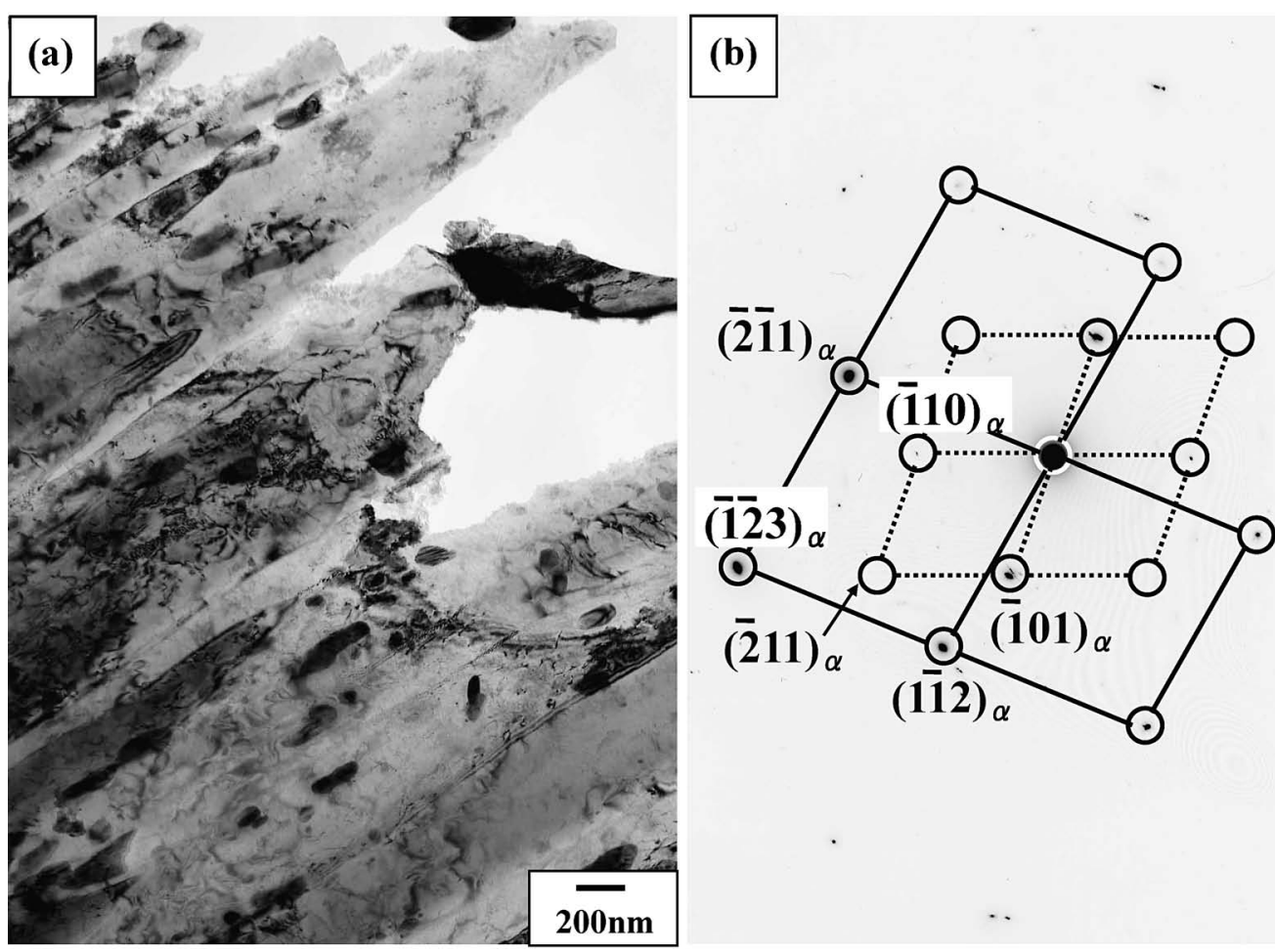

Fig. 11 (a) Bright-field transmission electron micrograph taken from blocks of bainite laths and (b) diffraction pattern taken from (a). The diffraction pattern indicates that the blocks consist of 2 kinds of laths having (112) twinned relation with each other.

$2.62 \%$ となる。よって, 試料全体では $1.52 \% \times(1 / 4)+$ $2.62 \% \times(3 / 4)=2.35 \%$ 割合でベイナイト・ラス間のすべ り面抢よびすべり方向の両方の平行性が同時に良いことにな る.

一方, 結晶粒間に全く結晶方位関係が存在しない多結晶材 料について，前述のすべり面およびすべり方向が同時に $20^{\circ}$ 以内の平行性を保つ割合を算出した。結晶粒を半径 $r$ の 球体とすると，1つのすべり面の垂直方向に対して，開き角 $20^{\circ}$ の円錐で切り取られる半径 $r$ の球体の表面積の球体全表 面積に対する割合 $\mathrm{S}$ を求める.

$$
\mathrm{S}=2 \pi r^{2} \int_{0}^{\pi / 18} \sin \theta \mathrm{d} \theta / 4 \pi r^{2}=0.0152
$$

すべり面， $\{110\} \alpha$ および $\{112\} \alpha ，$ の全枚数は 36 枚である から， 1 個の結晶粒表面につき最大で $0.0152 \times 36=0.547$ の 割合ですべり面の垂直方向に対して, 開き角 $20^{\circ}$ の円錐で 切り取られる球体の表面積が存在する。したがって, $(0.547)^{2} / 2=0.150$ の割合ですべり面の平行性が与えられ る. 次に，すべり方向同士の平行性について考える.すべり 方向 $\langle 111\rangle \alpha$ は，1枚の $\{110\} \alpha$ については 4 方向 (1つの方向 について逆方向も考慮する)， $\{112\} \alpha$ については 2 方向であ るから，合計 6 方向となり， $(0.0152 \times 6)^{2} / 2=4.16 \times 10^{-3}$ の割合ですべり方向の平行性が良いことになる。したがっ て，すべり面とすべり方向が同時に良い平行性を有する割合 は， $0.150 \times 4.16 \times 10^{-3}=6.24 \times 10^{-4}$ となる．つまり， $0.06 \%$ となる.

つまり，ベイナイトが K-S の結晶方位関係を有する場合 (平行性が良い割合 : $2.35 \%$ ) は, 結晶方位関係が存在しない 多結晶材料の場合 (平行性が良い割合：0.06\%)に比べて, 約
39 倍も平行性の高いことが伺える。したがって，1個のべ イナイト・ラス中の剪断歪が隣接するべイナイト・ラスの変 形によって緩和される確立は, 多結晶材料におけるそれより も高いことを示唆しており，転位の局所的もしくは集中的な 蓄積を抑制する可能性が高い。このことは, 材料の割れを誘 発しにくいことに繋がろう。

ところで，本研究に用いた試料においては，ブロック (block) が形成されている領域もあり，Fig. 11 に見られるよ うに双晶関係にあるバリアントから成っている. そこで, 双 晶関係にあるバリアント間におけるすべり面抢よびすべり方 向の平行性を調べたところ, 平行性が良い割合は，1.00\%で あった，一方，双晶関係になく，同一晶癖面上に存在する 6 種類のバリアント間では, すべり面㧍よびすべり方向の平行 性は $1.52 \%$ であることから，ブロックを形成せず，各種の バリアントが形成されるほうが材料の割れを誘発しにくいと 考えられる.

また, 変形後の一個のベイナイト・ラスの鋭い一方向への 表面起伏の干渉顕微鏡による観察結果 2 から, 1 個のベイナ イト・ラスの剪断歪は〜 $15 \%$ に上る. つまり， 1 個のベイナ イト・ラス内で 1 つすずり系が顕著に活動している。し たがって，極端な多重すべりは，困難であると考えられる。 理由は, 高密度の転位間での弾性的相互作用は非常に大き く, 多重すべりの導入前に他のベイナイト・ラスでの変形が 生ずると考えるのが妥当である。したがって，主すべり系が 変形を支配する大きな要因であると考えられ，1個のべイナ イト・ラスの変形によって生じた内部応力に対して最大のシ ュミット因子を有する隣接ベイナイト・ラス内のすべり系が 活動すると考えられる，この実験結果は，上記の解析結果を 
支持するものであり，「ベイナイト・ラス間のすべり系の平 行性」が変形過程を支配する重要な因子であることを意味す る。つまり, ベイナイト鋼の勒性向上にとって, 粒内ベイナ イトの生成が非常に重要であると結論できる.

粒内べイナイトを如何に核生成させるか，という課題につ いては, 酸化物, 窒化物, ホウ化物あるいはこれらの複合化 合物などが粒内べイナイト核生成に寄与するが，これらは割 れの起点になりやすい。そこで，これらの化合物を可能な限 り利用せずに粒内ベイナイトの核生成を促進さす必要があ る。また，ベイナイト特有の炭化物，特に，B-II型に抢け るセメンタイトは, ベイナイト・ラス間の変形歪の伝播の妨 げとなり，割れを発生させやすい。したがって，B-Iおよ び B-III型ベイナイトの利用が望ましいと考えられる.

\section{4. 実用化へ向って}

粒内ベイナイトが微細粒であるがゆえに高強度に寄与する ことは明白であるが，耐衝撃性向上に大いなる効果があるこ とも実験的に確かめられている10)。そこで，実用化を目指 すとなると，経費を抑えて粒内ベイナイトを多量に導入しな ければならない。このときに注意しなければならない点は， 粒界ベイナイトが生成されないようにすることである，粒界 ベイナイトは，成長が早く，勒性低下につながるので，その 核生成を抑制しなければならない，現在，研究が進行中であ るが，Mn 系酸化物，あるいはその複合酸化物がオーステナ イト粒界に核生成すると，その成長につれて粒界およびその 近傍の Mn 濃度の低下に起因して粒界ベイナイトが生成さ れやすくなる11). しかし，一方，MnS や上記の酸化物抢よ び Mn 系窒化物は, 粒内ベイナイトをも核生成しやすくす る．そこで，ベイナイト変態が一種の剪断変態であることに 着目して，オーステナイト粒内に格子欠陷を利用して剪断歪 場の導入を試みた。我々は， $\mathrm{S}$ 添加による小傾角粒界の導入 を試み，ほぼ試料全体を粒内べイナイトで満たすことができ た ${ }^{12)}$. 今後, 小傾角粒界に限らず，オーステナイト粒内に 格子久陥の導入を試みて鉄鋼材料内に剪断歪場の導入を図る と同時に連続冷却過程で粒内ベイナイトの核生成を促進さす ことが肝要である. 但し, ベイナイト変態が剪断変態的要素 を有することを利用しようとしているが，多種のバリアント から成るベイナイト・ラスの導入のためには，格子欠陥でさ えあれば良いということはない。ある程度，短周期(ベイナ イト・ラス幅あるいはそれ以下)の歪場変動が要求されよう.

もう一つの問題点は，指摘したように勒性向上のためには ベイナイトがその界面(晶㾕面)に炭化物を有しない B- I も しくは B-III型でなければならないことである。C および合 金元素組成制御による組織制御も視野に入れなければならな い. 容易なことではないことは, 予想が着くが不可能とは思 えない.「今後とも挑戦する」に尽きる.

\section{5. ま め}

（1）ベイナイト.ラスは非常に微細であるので，1つのべ イナイト・ラス内での極端な多重すべりは，困難であると考
えられる，理由は，高密度の転位間での弾性的相互作用は非 常に大きく，多重すべりの導入前に他のベイナイト・ラスで の変形が生ずると考えるのが妥当である。したがって，外部 応力に対する主すべり系，抽よび内部応力に対してシュミッ 卜因子が大きいすべり系が変形を支配する大きな要因である と考えられる.

(2) 1 個のバリアントの変形による転位の増殖集団が隣接 するバリアントの変形を誘起するという下部組織の観察結果 から，一般に，1個のバリアントの剪断歪の緩和が隣接する バリアントの変形によって生ずるのではないかと考えられ た．そこで，隣接バリアント間のすべり系の平行性(すべり 面およびすべり方向同士が $20^{\circ}$ 以内）をステレオ解析法にて 調べた結果, 同一晶癖面のバリアント間では $1.52 \%$, 異種

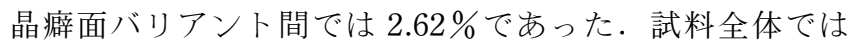
$2.35 \%$ である。一方，結晶粒間に全く結晶方位関係が存在し ない多結晶材料に打けるそれは，0.06\%であることからべイ ナイト・ラスに抢ける結晶方位関係，Kurdjumov-Sachs の 関係: $\{011\} \alpha / /\{111\} \gamma,\langle 11 \overline{1}\rangle \alpha / /\langle 10 \overline{1}\rangle \gamma$ 抢よび $\langle\overline{2} 1 \overline{1}\rangle \alpha / /$ $\langle\overline{1} 2 \overline{1}\rangle \gamma$ ，がべイナイト鋼の機械的性質の改善に大いに役立 つことが期待される.

（3）一般に見られるベイナイト・ラスは，結晶粒界から核 生成して抢り，同一晶癖面に沿って成長していることが多い (粒界ベイナイト). 隣接するべイナイト．ラスは双晶関係に あるものが多いが，すべり系の平行性は良くなく，割れの発 生が生じやすいことが示唆できた。したがって，ブロックや ブロックの集合体であるパケットが細かいほうが各種のバリ アント同士が隣接する可能性が高くなるので，勒性向上が期 待できる。

社)日本鉄鋼協会発刊の学術雑誌「鉄と鋼 (Vol. 90 (2004), 574-580. およびVol. 91 (2005)，882-887.)」から図などの 転載許可を頂いた。ここに深甚なる謝意を表します。

\section{文献}

1) K. Nakai and Y. Ohmori: Materia Japan 40(2001) 52-58.

2) K. Nakai, T. Megumi, S. Kobayashi, M. Hamada and Y. Komizo: TETSU-TO-HAGAŃE 90(2004) 574-580.

3) K. Nakai, T. Megumi, S. Kobayashi, M. Hamada and Y. Komizo: TETSU-TO-HAGANE 91 (2005) 882-887.

4) R. L. Klueh, D. J. Alexander and E. A. Kenik: J. Nucl. Mater. 227 (1995) 11-23.

5) R. L. Klueh and D. J. Alexander: J. Nucl. Mater. 265(1999) 262-272.

6) M. J. Balart, C. L. Davis and M. Strangwood: Mater. Sci. Eng. A328(2002) 48-57.

7) K. Laha, K. S. Chandravathi, K. B. S. Rao, S. L. Mannan and D. H. Sastry: Int. J. Pressure Vessels Piping 77 (2000) 761-769.

8) D. Q. Bai, S. Yue, T. M. Maccagno and J. J. Jonas: ISIJ Int 38(1998) 371-379.

9) N. Shikanai, H. Kagawa and M. Kurihara: ISIJ Int. $32(1992)$ 335-342.

10) M. Hamada, S. Okaguchi, Y. Komizo, A. Yamamoto, N. Takahashi, T. Ikeda and I. Takeuchi: Proc. of the International Pipeline Technology Conference, Published by Scientific Surveys Ltd., UK. 3(2004) 1077-1088.

11) K. Nakai, K. Kibata, S. Kobayashi, M. Hamada and Y. Komizo: to be submitted.

12) N. Kanno, K. Nakai, S. Kobatashi, T. Sakamoto, M. Hamada and Y. Komizo: CAMP-ISIJ 19(2006) 454 